Egyptian Journal of Aquatic Biology \& Fisheries

Zoology Department, Faculty of Science,

Ain Shams University, Cairo, Egypt.

ISSN $1110-6131$

Vol. 24(3): 181 - 191 (2020)

www.ejabf.journals.ekb.eg

\title{
Isopod parasites in the Egyptian fisheries and its impact on fish production: Lake
} Qarun as a case study

\author{
Sahar Fahmy Mehanna \\ National Institute of Oceanography and Fisheries \\ P.O.Box 182, Suez, Egypt \\ Sahar_mehanna@yahoo.com
}

\section{ARTICLE INFO \\ Article History: \\ Received: May 2, 2020 \\ Accepted: May 14, 2020 \\ Online: May 17, 2020}

Keywords:

Fishery resources;

Isopod parasites;

Lake Qarun;

Egypt;

Catch statistics;

Management

\section{INTRODUCTION}

Isopods associate with many species of commercially important fishes around the world and cause significant economic losses to fisheries by killing, stunting or damaging these fishes. Also, infestation by different type of parasites causes significant loss of fish condition in cases of heavy infestation. This in turn may result in reduced growth rates, reduced reproductive effort and greater mortality. Parasitic isopods are typically marine, and usually inhabit the warmer seas and infect fish but also other crustaceans. Though free-living isopods tend to be detritivores, parasitic forms feed on host blood or host haemolymph. Their mouthparts form a cone with maxillipeds that tear at the flesh and tiny pointed mandibles that pierce into the tissue to penetrate blood vessels or blood sinuses. Most parasitic isopods are ectoparasites. There are three major groups: 
Cymothoids, Epicaridians and Gnathiids. Cymothoids are parasites of fish, both as immature forms and adults. Cymothoids are obligatory parasites infesting many of the commercially important fishes. They are protandric hermaphrodites and bloodsuckers, living on the skin, gill filaments, or in the mouth of the fishes. These parasites retard growth and cause emaciation followed by death. Cymothoid isopods have been mentioned in some of the earliest references on natural history, e.g. Belon (1553) and Rondelet (1554) but despite this long history, they are still incompletely known or even completely unknown in many parts of the world (Trilles, 1994; Hadfield, et al., 2010). Trilles (1994) provided a world catalogue of the Cymothoidae, which highlighted the lack of information of fish parasitic isopods particularly in eastern, Northern Africa, South Africa, South America and Asia.

The information regarding cymothoid fauna of marine fishes from the Egyptian coasts is very rare. So, the present study reports the outbreak and infection of isopod parasites in the largest inland natural ecosystem in Egypt, Lake Qarun and its impacts on the fish production of the lake.

\section{MATERIAL AND METHODS}

\section{Study area}

Lake Qarun is considered the oldest natural lake in Egypt, located in the western desert in the lowest part of El-Fayoum depression about $90 \mathrm{~km}$ southern Cairo between

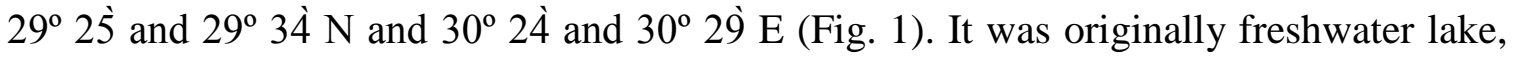
and changed to saline water ecosystem in the early 1900s due to decreased freshwater inflow coupled with high evaporation rate. It has about $230 \mathrm{Km}^{2}$ of water surface with a rich biological diversity including birds, plants and fishes (Fouda, 2012). In the past, the lake was a reservoir for the Nile flood and contained several species of the Nile fishes.

Now, lake Qarun is an isolated saline basin with no apparent outlets and used as reservoir for drainage water of the cultivated lands in El-Fayoum Province. It has a rectangular shape with maximum depth of 8 meters. However, most of the lake is less than 6 meters. The lake lies at $44.3-44.8 \mathrm{~m}$ below the sea level. Most of the drainage water reaches the Lake via two main drains namely El-Bats (east) and El-Wadi (middle) drains. Lake Qarun has been undergoing a progressive increase of salinity due to the continuous supply of the slightly brackish land-drainage water and the excessive evaporation caused by high temperature in summer. El-Batts Drain (50.9 Km long) receives agricultural drainage water from the eastern and north eastern side of Fayoum depression. El-Wadi Drain $(48.5 \mathrm{Km}$ long) receives water from the middle of El-Fayoum Governorate. These drains affect negatively the lake's water quality and consequently affect the lake's fish production. 


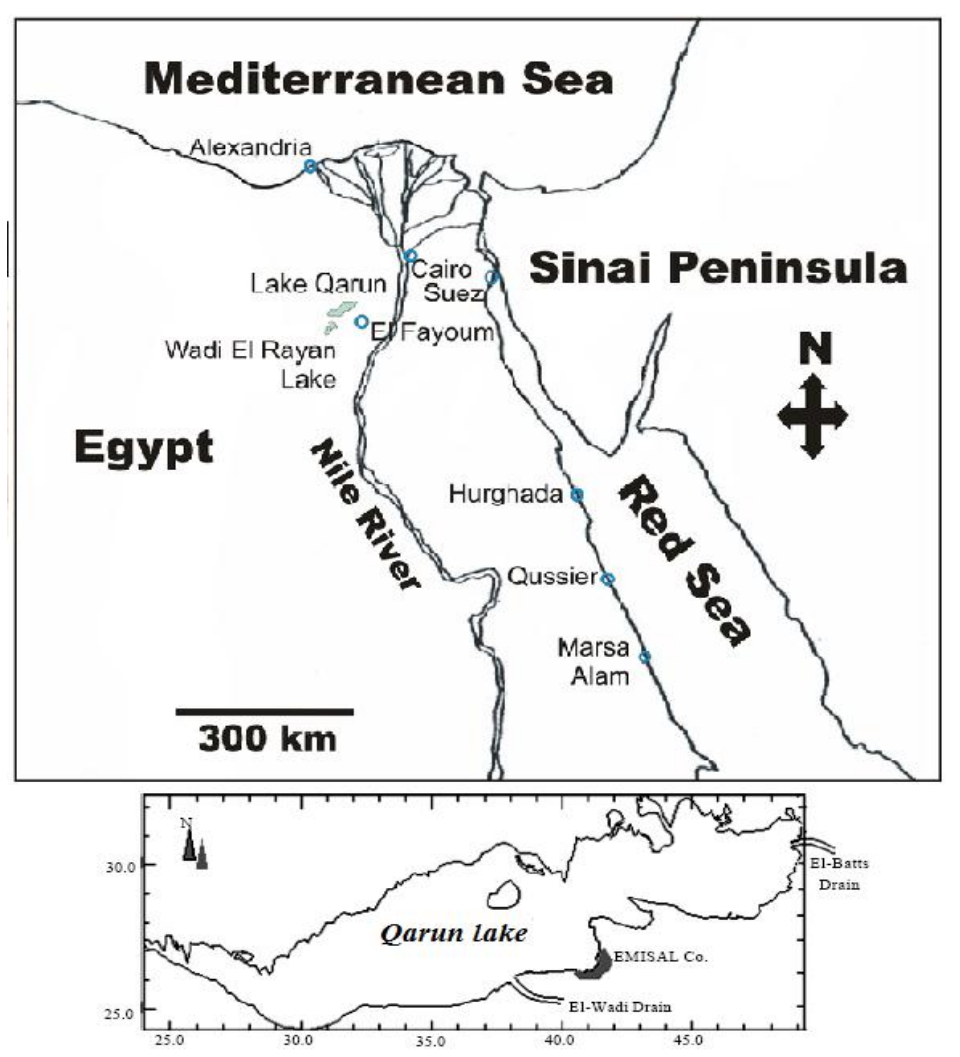

Fig. 1: Lake Qarun

\section{Fishery statistics}

Data concerning the annual total catch and catch by fish group as well as the fishing effort were obtained from the annual statistical book of General Authority for Fish Resources Development GAFRD. While the catch composition and types of fishing gears were observed during the field trips.

\section{Field trips and sampling}

Twelve field trips (6 days per trip) were conducted to the lake during the period from 2014 to 2016, eight of them were conducted through the Fish Population Dynamics Lab plan to study the fisheries status of lake Qarun and the extra four were conducted to follow up the outbreak of isopod parasites and its impact on the lake fish production. Seventy two visits to the landing sites and interviewing the fishermen as well as the traders were done during the period of study. The following information was collected: Fishing effort exerted into the lake (gears and methods, mesh sizes, height and length of nets, boats' lengths, number of fishermen per boat), catch composition, current challenges facing fishermen in the lake and the socio-economic situation. During the sampling program to study the biology and dynamics of the commercial fish species in lake Qarun, a total of 500 specimens of Tilapia zilli ( $5-20 \mathrm{~cm}$ TL; $3-95 \mathrm{~g}$ in weight), 350 specimens of Solea aegyptiaca (10 - $22 \mathrm{~cm}$ TL; $9-120 \mathrm{~g}$ in weight) and 300 specimens of Liza ramada $(14-28.5 \mathrm{~cm}$ TL; $30-225 \mathrm{~g}$ in weight) were randomly sampled to investigate 
the rate of infestation (Fig. 2). The isopod parasites were identified according to Bruce (1986 \& 2004), Trilles (1994 \& 2008) and Rameshkumar, et al. (2011).

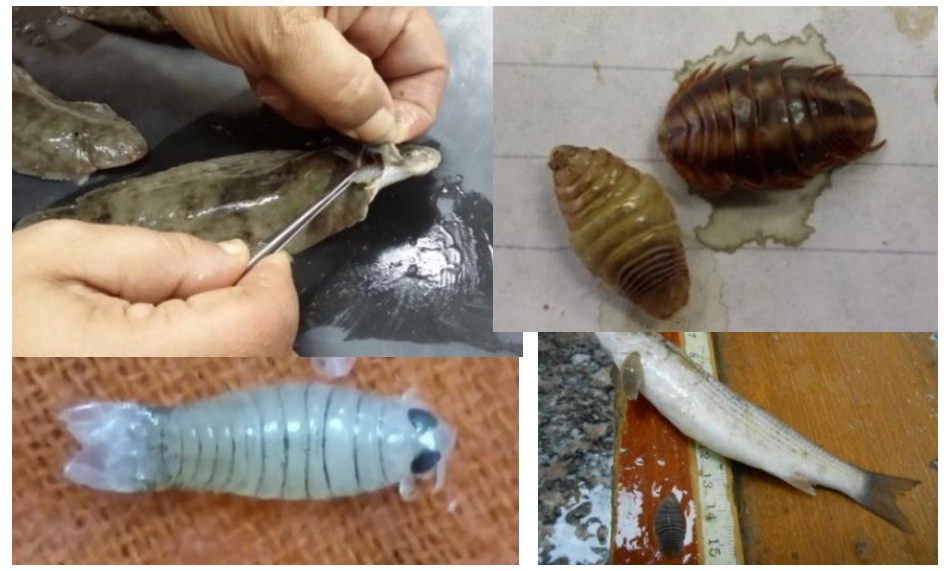

Fig. 2: Some pictures from the Lab during the fish investigation

\section{RESULTS \& DISCUSSION}

\section{Catch composition}

Since the lake Qarun was fresh water, its fisheries production contained most of Nile fishes (Faouzi, 1936 \& 1938) such as Lates niloticus, Clarias anguillaris, Labeo niloticus, Barbus bynni and Tilapia spp. By the time, all fresh-water species with the exception of Tilapia spp. and Anguilla spp. gradually disappeared from the lake depending on their tolerance to salinity (El-Zarka, 1961 \& 1963). The commercial catch dropped from 4000 ton during 1920 to an average of 1 to 2 thousand ton in subsequent years. To compensate the decline in fish production due to the disappearance of fresh water fish species, some marine fishes, like Mugil spp. and Solea spp. followed by Sparus aurata, Dicentrarchus labrax and shrimps, were introduced and transplanted to the lake. Some species like, Atherina spp. were accidentally introduced as fry mixed together with mullet fry (Anonymous, 2007). Liza saliens, Solea spp. and shrimps were succeeded to acclimatize and spawn in the lake.

Mullet fry were transplanted into the lake in 1928 and continued to the present time, while Sole were transplanted into the lake since 1930. The gilthead seabream Sparus aurata, was first introduced in the lake in 1970, but in relatively small numbers. The stocking rate was increased in 1976 and 1977. The seabass, Dicentrarchus labrax, and some shrimp species larvae were accidentally transplanted into the lake along with seabream. Since 80's, the most dominant fish species in the catch were tilapia (Family: Cichlidae), grey mullet (Family: Mugilidae), flatfish (Family: Soleidae), and shrimp (Family: Penaeidae). These four groups constitute up to $96 \%$ of the lake production where the other important species like seabass, seabream and European eel are rarely appeared. On the other hand, some of lesser important species like Atherina and Siganus 
started to appear but still in small quantities (Fig. 3). From the field observations, it could be said that there is no accurate recording for fishery statistics and catch composition. A number of species were recorded in the catch without any referring in the annual statistical book of GAFRD, these species are Gobius, Engraulis, Terapon, seahorse and crabs. Also, the catch composition by species for each group not reported, for example the mullet group composed of six species and tilapias are composed of three species.

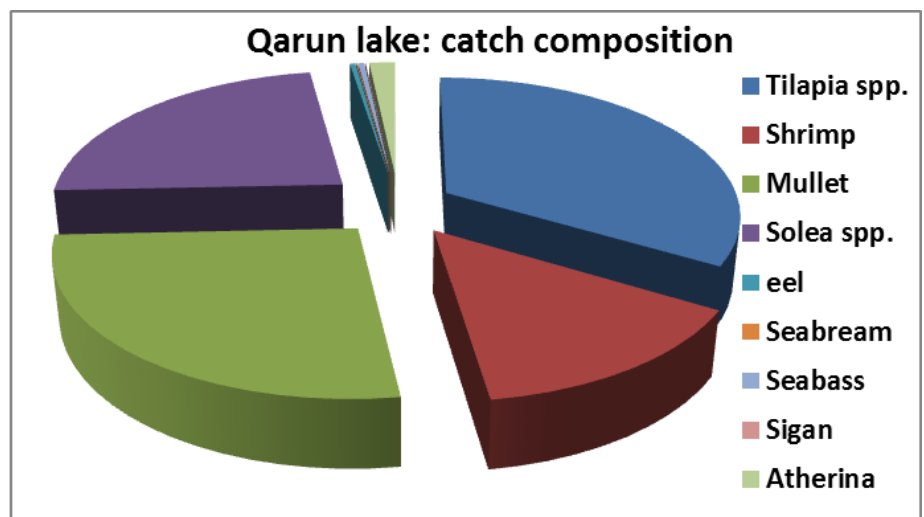

Fig. 3: Catch composition of lake Qarun as an average for the period from 2005 to 2017

\section{Catch statistics}

The annual total fish production and the catch by species from Lake Qarun during the period from 2005 to 2017 were fluctuated between a maximum value of 4518 ton during 2014 and a minimum of 878 ton during 2016 with a mean of 3000 ton (Fig. 4), while the total catch of tilapia was varied from a maximum of 1454 ton during 2008 to a minimum value of 225 ton during 2017 with a mean of 994 ton. The total catch of grey mullet was varied from a maximum of 1424 ton during 2011 to a minimum value of 142 ton during 2017 with a mean of 788 ton, while the sole catch varied from a maximum of 1111 ton during 2014 and a minimum 137 ton of during 2017 with a mean of 686 ton (Fig. 5). In 1955, the mullet production contributed $21 \%$ of the commercial catch (Ishak and Abdel Malek, 1980). During 70's, sole production ranks at the top of other species, where it contributed more than 50\% of lake fisheries production till 1978 (Bishai and Kirollus, 1987). On the other hand, the shrimp catch showed a great fluctuation ranging from a maximum of 912 ton during 2012 to a minimum of 91 ton during 2017 with a mean of 421 ton during the period from 2005 to 2017 (General Authority for Fish Resources Development GAFRD annual reports).

By 2015, the lake production showed a serious decline due to the very bad water quality which leads to the flourishing of isopod parasites to the first time in the lake. All fish species collected in this year and the subsequent years were found to be heavily infected by the cymothoid parasites. During this period (2015 to 2017), the fishermen couldn't earn their expenses and most of them stopped to fish because the fish species lost their economic importance as most of them was infected and did not grow to the economic 
sizes as well as lost their market. Afifi (2015) mentioned that small fish disappeared from all sites at Lake Qarun and attributed this disappearance to the heavily abundance of crustacean parasites, which come from Mediterranean Sea with fish fry and caused severe damage to fish stock in the lake. Helal and Youssef (2018) found that cymothoid isopod, Livoneca redmanii causes economic loss associated with reduced fish growth, high mortality and marked drop in fish production from Lake Qarun.

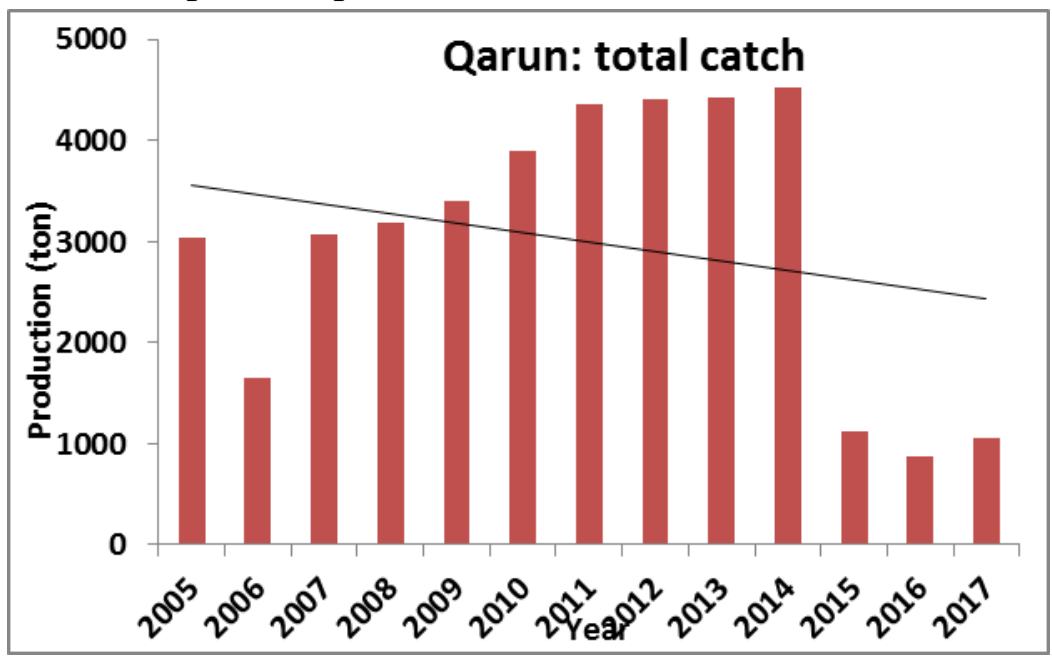

Fig. 4: Total catch (ton) from lake Qarun from 2005 to 2017

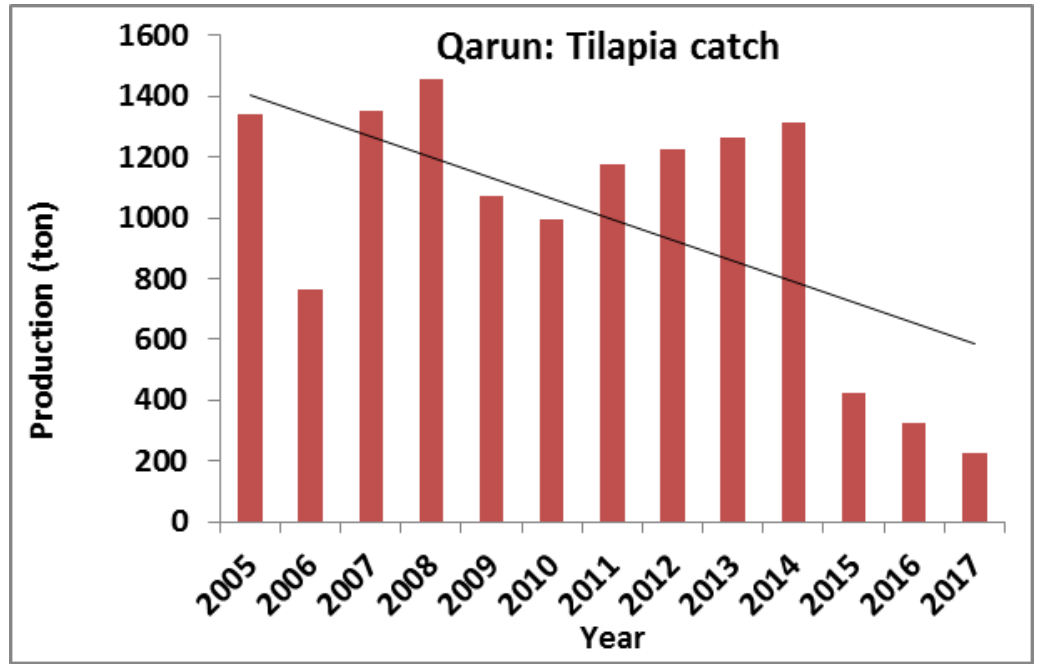



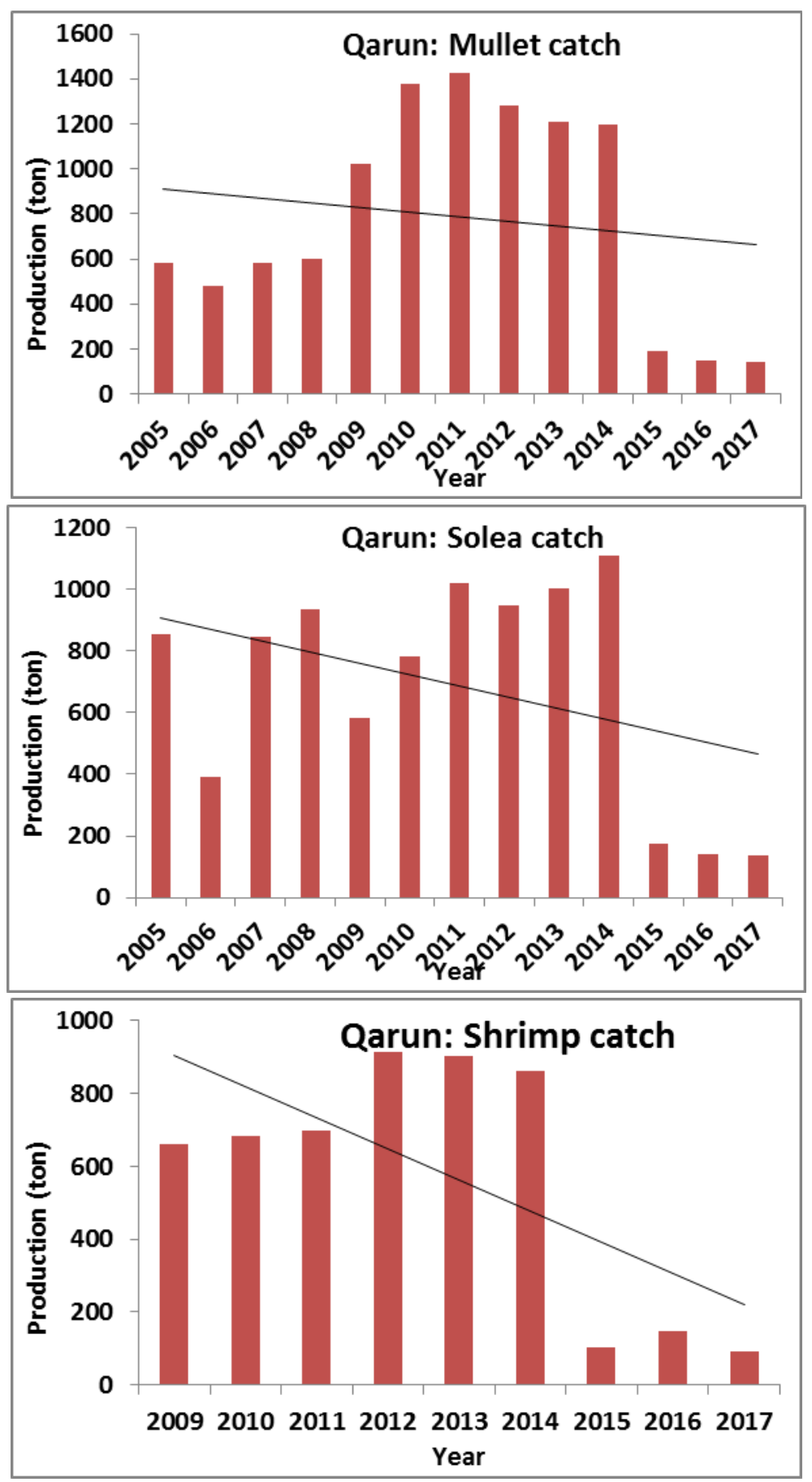

Fig. 5: Catch (ton) of the four main fish groups in lake Qarun

\section{Fishing effort}

Some 700 non-motorized wooden fishing boats are operating in the lake. Their length varied from 5 to 7 meters. The recorded number of fishermen is about 3000 (nearly 4 persons per boat) with an age ranged from 15 to 65 years old. Trammel, seine, hooks and gill nets are the most common used nets. Trammel nets are classified according to their target species and specifications to Ghazl Bory which targeting Mugil cephalus, Ghazl Bolti which targeting Tilapia spp. Ghazl Mossa which targeting sole spp. 
and Ghazl Fahhar which targeting Liza spp. These four types of trammel nets are modified to catch their target species, therefore the target species contributed for at least $55 \%$ of the gear total catch. The seine nets can be classified into Beach Seine (Gorafat Sardina which is mainly targeting Anchovy and Gorafat Bory which is targeting Mugil cephalus) and Boat Seine or Hattata which targeting soles, tilapia and shrimp. Besides some others fishing gears such as Fish Aggregating System (FAS) or heml, traps or goaby and hooks or sinnar are used in the lake. It is worth mentioning that before 2014 the main challenges facing the fish production from the lake were the excessive fishing effort, illegal fishing gears with small mesh sizes like seine nets and pollution due to the untreated drainage water that discharged directly into the lake (Anonymous, 2007; Hussein et al., 2008; Abou El-Gheit et al., 2012; Ibrahim and Ramzy, 2013; KhalafAllah, 2014; El-Serafy et al., 2014: Mehanna et al., 2015; Khalil et al., 2017).

\section{Cymothoid infestation}

Isopod parasites of the family Cymothoidae has been reported in about 350 fish species worldwide. Over $80 \%$ of these are from tropical and subtropical seas, many are from the Indo-Malaysian archipelago (Lester and Roubal, 1995). Their life cycle involves only one host (holoxenic cycle) (Trilles, 1994) and usually these are large sized parasites, which can cause deleterious effects on the host fishes (Trilles, 2008). During the study period, two cymothoid species were identified through the fish examination, Livoneca redmanii and Anilocra spp. (Isopoda, Cymothoidae). We found these parasites on the almost fish species caught from the lake (Tilapia, mullet and sole) with high percentages of infestation. The prevalence is $83 \%$ in sole, $75 \%$ in mullet and $57 \%$ in Tilapia and the number of parasite per hosted fish was from 1 to 4 parasites in gills region or attached on the skin. The rate of infestation in the present work was considerably higher than that recorded in the Egyptian waters. Badawy (1994) reported a percentage of infestation as $8.6 \%$ from Mediterranean Sea at Port-Said, while Abd El-Aal and ElAshrum (2011) gave 9\% in the Argyrops filamentosus from Mediterranean Sea at Matrouh province. Eissa, et al. (2012) found that an infestation percentage of $19 \%$ was recorded among Mediterranean Sea fishes and 24.4\% in fishes collected from Suez Canal in Ismailia province. Samn, et al. (2014) noticed that Nerocila bivittata infected $10.3 \%$ of Lithognathus mormyrus collected from Abu Qir Bay, Alexandria, Egypt. Mahmoud, et al. (2016) revealed total prevalence of $32.7 \%$ with isopod infestation among D. Labrax, S. vulgaris and $T$. zilli from lake Qarun with two cymothoid species Renocela thresherorum and Nerocila orbignyi. Abdel-Latif (2016) estimated a rate of 6\% infestation by Nerocila orbignyi which isolated from the gill chambers of Tilapia zilli collected from Qarun lake. Helal and Yousef (2018) found that the percentage of infestation of Mugil cephalus by Livoneca redmanii in lake Qarun was 47\% during 2016. Ali and Aboyadak (2018) estimated the prevalence of Renocela thresherorum infestation in lake Qarun during one month, May 2015 at 37.1, 25.7 and 53.3\% for 
Tilapia zilli, Mugil capito and Solea aegyptiaca respectively. These prevalence variations might be attributed to the differences in the periods of investigation, the examined fish species and the geographical distribution of fish hosts and parasites. It was observed that the fish production from lake Qarun is severely declined after 2014 coincides with the isopod outbreak in the successive years. This intensive isopod infestation affected the growth rate, fecundity and mortality rates. Also, the infected fishes became highly susceptible to bacterial infection and other fish diseases. Consequently, the fishes of lake Qarun have lost their economic values and their markets and this is negatively affected the fishermen communities in the lake.

\section{Government efforts}

The government at first tried to compensate the decline in fish production of the lake by stocking it by millions of shrimp and mullet fry but a mass mortality of these fry was happened due to the very bad quality of water. Then many efforts were started to improve the water quality of the lake such as the construction of sewers and sewage treatment facilities in El-Fayoum governorate, control water pollution, especially from municipal and industrial effluents and control of wastewater discharges and drainage to the lake from El-Bats and El-Wadi drains.

\section{CONCLUSION}

The serious decline in fish production and the low productivity of lake Qarun is a direct result of irrational exploitation, severe pollution and poor non-effective management policies. To improve and develop the lake fisheries, the following steps should be implemented: 1) Improve the water quality of the lake particularly treatment of discharged water of El-Bats and El-Wadi drains. 2) Stock the lake with marine fish species especially grey mullet, seabream, sea-bass and shrimp. 3) Monitor the fish health in the lake. 4) Improve the specifications of the fishing gears used and prohibition the illegal nets. 5) Improve the catch statistics recording system. Besides, a more intensive sampling program was required to better understand the variation in temporal (seasonal) and spatial prevalence of infestation symptoms displayed in fish and crustacean species. Also, more research based on the molecular identification should be done to be sure about the isopod species identification as all the published data on lake Qarun are highly agreed in the genus name but rarely agreed in the species name for the isopod parasites recorded in the lake Qarun fishes.

\section{REFERENCES}

Abd El-Aal, A.M.I. and El-Ashrum, A. M. (2011). A morphological study (SEM) on a parasitic marine isopod, Cymothoa spinipalpa (isopoda: Cymothoidae). Egyptian J. Aquaculture, 1: 17-26. 
Abou El-Ghaeit, E.N.; Abdo, M.H. and Mahmoud, S.A. (2012). Impacts of blooming phenomenon on water quality and fishes in Qarun Lake, Egypt. Inter. J. Envir. Sci. \& Eng. (IJESE), 3: 11-23.

Abdel-Latif, H.M. (2016). Cymothoid parasite, Nerocila Orbigni inflicts great losses on Tilapia Zilli in Lake Qarun at El-Fayoum Province. International Journal of Innovative Studies in Aquatic Biology and Fisheries, 2 (3): 1-9.

Afifi, M.A.M. (2015). Ecological and biological studies on pipe fish in Lake Qarun. M.Sc. Thesis, Zool. Dep. Fac. Sci., Al-Azhar Univ., Egypt, pp. 264.

Anonymous (2007). Trends of biological parameters of Lake Qarun ecosystem. Nat. Inst. Oceano. Fish. (NIOF), Final report, submitted to CDM Company Internat.INC.

Ali, N.G. and Aboyadak, I.M. (2018). Histopathological alterations and condition factor deterioration accompanied by isopod infestation in Tilapia zilli, Mugil cephalus and Solea aegyptiaca from lake Qarun. Egyptian Journal of Aquatic Research, 44: 57-63.

Badawy, G.A. (1994). Some studies on ectoparasites infecting marine fish in Egypt. Ph. D. Thesis, ParasitoL. Dept. Vac. Vet. Med. Zag. Univ.

Belon, P. (1553). De Aquatilibus, libri duo: cum conibus ad viuam effigiem, quoad eius fieri potuit, expressis. Paris, pp. 448.

Bishai, H.M. and Kirolus, S.Y. (1988). Net selectivity of Solea vulgaris in Lake Qarun, Egypt. Bull. Fac. Sci., Cairo Univ., 56: 209-219.

Bruce, N.L. (1986). Australian Pleopodias Richardson, 1910 and Anilocra Leach, 1818 (Isopoda, Cymothoidae), Crustacean Parasites of Marine Fishes. Rec. Aus. Mus., 39: 85-130.

El-Serafy, S.S.; El-Haweet, A.A.; El-Ganiny, A. and El-Far, A.M. (2014). Qarun Lake fisheries; Fishing gears, Species composition and Catch per unit effort. Egypt. J. Aquat. Biol. \& Fish., 18 (2): 39- 49.

El-Zarka, S.E. (1961). Tilapia fisheries investigations in Egyptian lakes. II: A biological study of the fisheries of Tilapia zillii in Lake Qarun. Notes and memoirs No. 66: pp.44.

El-Zarka, S.E. (1963). Acclimatization of Solea vulgaris in Lake Qarun, Egypt. J. Cons. Perm. Int. Explor. Mer. 28: 126-136.

Eissa, I.A.M.; El-Lamie, M. and Zakai, M. (2012). Studies on crustacean diseases of seabass, Morone Labrax, in Suez Canal, Ismailia Governorate. Life Sciences J., 9(3): 512-518.

Faouzi, H. (1936). Successful stocking of Lake Qaroun with mullets (Mugil cephalus, Linn., and Mugil capito, Cuv.) from the Mediterranean. Int. Rev. Hydrobiol.., 33:434-439.

Faouzi, H. (1938). Rapports sur les pecheries d'Egypt en 1935.Ministeredu Commerce et de 1' Industrei. 133p.

Fouda, M. (2012). Information Sheet on Ramsar Wetlands (RIS) - 2009-2012 version, http://www.ramsar.org/ris/key_ris_index.htm.

GAFRD (2017). Annual fishery statistics report. General Authority for Fish Resources Development. Cairo, Egypt.

Helal, A.M. and Yousef, O.E. (2018). Infestation Study of Livoneca redmanii (Isopoda, Cymothoidae) on Mugil cephalus in Lake Qarun, Egypt . Egypt. Acad. J. Biolog. Sci. (B. Zoology), 10(1): 1-17

Hussein, H.; Amer, R.; Gadallah, A.; Refaat, Y. and Abdel-Wahab, A. (2008). Pollution monitoring for Lake Qarun. Adv. Environ. Biol., 2 (2): 70-80. 
Ibrahim, L.A. and Ramzy, E.M. (2013). Water quality and its impact on Tilapia zilli (case study) Qarun Lake-Egypt. International Water Technology Journal, 3(4): 170-191.

Ishak M.M. and Abdel-Malek S. A. (1980). Some ecological aspects of Lake Qarun, Fayoum, Egypt. Part I. Physico-chemical environment. Hydrobiologia, 74: 173-178.

Khalaf-Allah, H.M.M. (2014). Seasonal distribution and abundance of small fish in the south coast of Lake Qarun, Egypt, World Journal of Fish and Marine Sciences, 6 (1): 109-118.

Khalil, M.T.; Fishar, M.R.; Shakir, S.H.; Amer, A.S. and Nassif, M.G. (2017). Impact of drainage water on macrobenthos structure of Lake Qaroun, El-Fayoum, Egypt. Egyptian Journal of Aquatic Biology \& Fisheries, 21(2): 17-32.

Lester, R.J.G. and Roubal, F.R. (1995). Phylum Arthropoda. In: Woo P. T. K. (Ed.), Fish diseases and disorders, 1: Protozoan and Metazoan infections. CAB International, Wallingford:pp. 475-598.

Mahmoud, N.E.; Fahmy, M.M.; Abuowarda, M.M. and Khattab, M.S. (2016). Parasitic cymothoid isopods and their impacts in commercially important fishes from Lake Qarun, Egypt. International Journal of Chem. Tech. Research., 9 (12): 221-229.

Mehanna, S.F., et al. (2015). Qarun lake fisheries, its current situation and future management. Final report, Fisheries Division, NIOF, 55pp.

Rameshkumar, G.; Ravichandran, S. and Trilles, J.P. (2011). Cymothoidae (Crustacea, Isopoda) from Indian fishes, Acta Parasit., 56 (1): 78-91.

Rondelet G. (1554). Libri de Piscibus Marinis, in quibus verae Piscium effigies expressae sunt. Matthias Bonhomme, Lugduni, 583pp.

Samn, A.A.M.; Metwally, K.M.; Zeina, A.F. and Khalaf Allaha, H.M. (2014). First occurrence of Nerocila bivittata: parasitic Isopods (skin shedders) on Lithognathus mormyrus (Osteichthyes, Sparidae) from Abu Qir Bay, Alexandria, Egypt. Journal of American Science, 10 (7): 171-179.

Trilles, J.P. (1994). Les Cymothoidae du Monde. Prodrome pour une Faune. Stud. Mar., (21/22): $1-288$.

Trilles, J.P. (2008). Some marine isopods from the Senckenberg Research Institute (Frankfurt am Main, Germany) (Crustacea, Isopoda: Cymothoidae, Aegidae, Corallanidae, Cirolanidae). Senckenberg Biol., 88: 21-28

Youssef, E.M.; Salam, N.H.; Eissa, I.A. and Zaki, M.S. (2014). Parasitological studies on the isopoda (Cymothoidae) parasites infesting some marine fishes at Suez Canal area at Ismailia Province, Egypt with a key to the cymothoid genera. Life Sci. J., 11(1): 227-231. 